\title{
SCLEROTHERAPY WITH 75\% HYPERTONIC GLUCOSE TO TREAT DORSAL SYNOVIAL CYSTS OF THE WRIST
}

\author{
TRATAMENTO DO CISTO SINOVIAL DORSAL DO PUNHO COM \\ ESCLEROTERAPIA UTILIZANDO GIICOSE HIPERTÔNICA 75\%
}

\author{
Fernando araujo Pires ${ }^{1}$ (i), João Baptista Gomes dos Santos ${ }^{1}$ (i), Carlos Henrique Fernandes ${ }^{1}$ (i), \\ LUIS RENATO NAKASHIMA ${ }^{1}$ (i), FLÁVIO FALOPPA ${ }^{1}$ (1)
}

1. Universidade Federal de São Paulo, Paulista School of Medicine, Department of Orthopedics and Traumatology, São Paulo, SP, Brazil.

\section{ABSTRACT}

Objective: To evaluate the cure rate for dorsal synovial cysts of the wrist with aspiration and percutaneous sclerotherapy using 75\% hypertonic glucose. Methods: We enrolled 45 patients older than 18 years with untreated dorsal synovial cysts of the wrist. They underwent percutaneous aspiration and sclerotherapy with $75 \%$ hypertonic glucose $75 \%$. A maximum of two procedures were conducted for each cyst at a 4-week interval. We analyzed age, sex, affected side, history of previous trauma, wrist goniometry, grip strength, wrist pain by the visual analogue scale, complications, and hand function questionnaire scores. Results: We evaluated 45 patients (30 female, 15 male, mean age 38.2 years with 47 cysts). Four weeks after the first procedure, $72.3 \%$ cysts were palpable and visible. At 24 weeks after the first procedure, $57.4 \%$ cysts evolved to cure and $42.6 \%$ persisted. Conclusion: Treatment of dorsal synovial cyst of the wrist with aspiration and percutaneous sclerotherapy using $75 \%$ hypertonic glucose achieved a 57.4\% cure rate after 24 weeks. Level of Evidence IV, Case series

Keywords: Ganglion Cysts. Conservative Treatment. Sclerotherapy. Suction. Wrist.

\section{RESUMO}

Objetivo: Avaliar o índice de cura do cisto sinovial dorsal do punho, com aspiração e escleroterapia percutânea utilizando glicose hipertônica 75\%. Métodos: Foram selecionados pacientes maiores de 18 anos, portadores de cisto sinovial dorsal do punho, sem tratamento prévio. Foram submetidos a aspiração e escleroterapia percutânea com glicose hipertônica $75 \%$. Foi realizado no máximo dois procedimentos em cada cisto, em um intervalo de 4 semanas. Foram analisados idade, gênero, lado acometido, história de trauma prévio, goniometria, força de preensão, dor no punho pela escala visual analógica, complicações e os escores dos questionários funcionais. Resultados: Foram avaliados 45 pacientes com 47 cistos, houve perda de seguimento de 3 pacientes (3 cistos). A média de idade foi de 38,2 anos. Na quarta semana após o primeiro procedimento, tivemos cura em 23,4\% cistos, 4,3\% cistos apresentavam-se palpáveis porém não visíveis e 72,3\% cistos se apresentavam palpáveis e visíveis. Os cistos visíveis e palpáveis foram submetidos ao segundo procedimento. Após 24 semanas do primeiro procedimento, 57,4\% cistos foram curados e 42,6\% cistos apresentaram persistência. Conclusão: O tratamento do cisto sinovial dorsal do punho com escleroterapia percutânea utilizando Glicose Hipertônica 75\%, proporcionou cura de 57,4\% após 24 semanas. Nível de Evidência IV, Série de casos

Descritores: Cistos Glanglionares. Tratamento Conservador. Escleroterapia. Sucção. Punho.

Citation: Pires FA, Santos JBG, Fernandes CH, Nakashima LR, Fallopa F. Sclerotherapy with $75 \%$ hypertonic glucose to treat dorsal synovial cysts of the wrist. Acta Ortop Bras. [online]. 2021;29(2):101-104. Available from URL: http://www.scielo.br/aob.

\section{INTRODUCTION}

The synovial cyst is a benign soft tissue tumor mostly found in the dorsal topography of the wrist. ${ }^{1}$ It is more common between the 2nd and 4th decade of life and in the female gender. ${ }^{2}$ The cyst may be asymptomatic or cause local pain that is exacerbated with wrist movement.

The diagnosis is usually made by clinical examination and confirmed with ultrasound. ${ }^{1}$

There are numerous forms of treatment of the synovial cyst of the dorsal wrist: observational, aspiration of the cyst fluid, aspiration of the cyst fluid with corticosteroid infiltration, aspiration of cyst fluid and sclerotherapy, transcutaneous electrocautery and surgical treatment, which can be conducted openly or arthroscopicly. ${ }^{1-5}$ Open or arthroscopic surgical treatment has a cure rate of 70 to $100 \% .{ }^{6}$ However, it is invasive and has a higher rate of complications. ${ }^{7,8}$ Conservative treatment has a cure rate of 20 to $30 \% .{ }^{7}$ Few sclerosing agents have been studied for the treatment of dorsal synovial cyst of the wrist. There are only three published studies, two of which were case series and one was a randomized study. The first case series used a 2 cc solution of hypertonic serum associated

All authors declare no potential conflict of interest related to this article.

The study was conducted at the Department of Hand and Upper Limb Surgery at the Universidade Federal de São Paulo.

Correspondence: Fernando Araujo Pires. Rua Borges Lagoa, 778, São Paulo, SP, Brazil, 04038-030.drfernandoapires@gmail.com

Article received on 05/25/2020, approved on 08/19/2020. 
with $1 \mathrm{cc}$ of $1 \%$ lidocaine, resulting in cure for all patients. The author did not report complications after three days. ${ }^{9}$ The second case series used $3 \%$ polydocanol, with a cure rate of $96 \%$. The authors reported complications such as pain, edema and paraesthesia. ${ }^{10}$ The randomized study compared the use of hyalurocynal, triamcinololine and sodium tetradecyl sulfate in the treatment of synovial cyst in the wrist. He used the Single Dart technique, performing this procedure monthly, at most 3 times. It showed a recurrence rate of $25 \%, 20 \%$ and $35 \%$ respectively. ${ }^{8}$

Hypertonic glucose $75 \%$ is considered a safe sclerosingagent. ${ }^{11,12}$ The reported complications consist of edema, local urticaria that improved after 15 minutes of infiltration, transient glycemic elevation in patients with insulin resistance, transient neurological alteration that usually ceases within 2 hours in patients with migraines and arrhythmias. ${ }^{11}$

We believe that research into sclerosing substances that increase the cure rate will be useful for conservative treatment.

Our primary objective was to evaluate the healing index of the dorsal synovial cyst of the wrist with aspiration and percutaneous sclerotherapy using hypertonic glucose $75 \%$.

\section{MATERIALS AND METHODS}

This study is a case series, prospective, longitudinal, interventionist, approved by the Research Ethics Committee, conducted in a university hospital.

Female and male patients aged 18 years or older and less than 60 years of age with dorsal synovial cyst of the wrist were included. Exclusion criteria were a previous history of treatment, refusal of consent and diagnosis of Diabetes Mellitus.

The diagnosis of the dorsal synovial cyst of the wrist was made by clinical examination and complemented by ultrasound.

The pre-procedure data collected were age, affected side, gender and previous history of wrist trauma. The following characteristics were evaluated: the intensity of pain in the wrist, by the visual analog scale (VAS); wrist goniometry; the grip strength, by the mean JAMAR dynamometer; and applied the Quick Dash and Brief Michigan Hand Questionnaire.13,14

Patients were evaluated before the procedure and in the fourth, eighth, twelfth and twenty-fourth week after the procedure.

The procedure was performed by the single dart technique. ${ }^{8}$ We started with local anesthesia, by means of a $1 \%$ lidocaine injection with a 26-gauge needle in the subcutaneous proximal region of the cyst. In the same region, we introduced an 18-gauge needle, punctured the cyst and aspirated the synovial content. Next, a solution containing $3 \mathrm{ml}$ of hypertonic glucose $75 \%$ and $0.5 \mathrm{ml}$ of Lidocaine $1 \%$ was injected to perform cyst sclerotherapy. If the patient presented pain or discomfort, paracetamol was prescribed. In the fourth week after the procedure, the patient was asked about complications, the presence of pain or paraesthesia on the back of the wrist and if the patient observed hyperemia and edema. Regarding the criterion of cure of the cysts, we reevaluated all and distributed them into three groups: healing group (non-palpable and non-visible cyst); palpable and non-visible cyst group and palpable and visible cyst group. In the palpable and visible group, another procedure was conducted by the same technique.

In the eighth and twelfth weeks, the intensity of wrist pain was analyzed and the groups reclassified.

In the twenty-fourth week, all cysts were reevaluated and the groups reclassified, pain intensity was analyzed, wrist goniometry was performed, grip strength was measured and the Quick Dash and Brief Michigan Hand Questionnaire were applied. 13,14

All these data were added to a spreadsheet.

\section{Statistical method}

The statistical methods used were: paired Student's t-test and two-proportion equality test, with significance level less than 0.05 .

\section{RESULTS}

We treated 50 cysts in 48 patients between October 2017 and February 2018 and followed them for 24 weeks. Three patients were lost during the follow-up, totaling 47 cysts. Age ranged from 18 to 60 years, with a mean of 38.2 years. Among these, 15 were women and 45 men. Regarding the side, 24 were on the left side and 23 on the right. Only three (8\%) patients reported previous trauma to the affected wrist.

In the fourth week after the first procedure, we had a cure of $11(23.4 \%)$ cysts, two (4.3\%) cysts were palpable but not visible and $34(72.3 \%)$ cysts were palpable and visible. Those palpable and visible were subjected to the second procedure.

Table 1 shows the evolution of cysts in terms of cure in different periods.

Table 1. Evolution of cysts at 24 weeks.

\begin{tabular}{|c|c|c|c|c|c|c|c|c|c|c|c|}
\hline Order & $4 w$ & New procedure & $8 w$ & $12 w$ & $24 w$ & Order & $4 w$ & New procedure & $8 w$ & $12 w$ & $24 w w$ \\
\hline 1 & PV & $Y$ & PNV & PV & PV & 26 & PV & $Y$ & PNV & PNV & PNV \\
\hline 2 & PV & $Y$ & PNV & PNV & CURE & 27 & PV & $Y$ & PV & PV & PV \\
\hline 3 & PV & $Y$ & CURE & CURE & CURE & 28 & PV & $Y$ & PV & PNV & CURE \\
\hline 4 & PV & $Y$ & PV & PV & PV & 29 & PV & $Y$ & PNV & CURE & CURE \\
\hline 5 & PV & $Y$ & CURE & CURE & CURE & 30 & LOST FOLLOW-UP & & & & \\
\hline 6 & PV & $Y$ & PV & PV & PNV & 31 & PV & $\mathrm{Y}$ & PV & PV & PV \\
\hline 9 & PNV & $\mathrm{N}$ & PNV & PNV & CURE & 34 & CURE & $\mathrm{N}$ & CURE & CURE & CURE \\
\hline 10 & PV & $Y$ & PV & PV & PV & 35 & PV & $Y$ & CURE & PV & PV \\
\hline 11 & PV & $Y$ & PV & CURE & CURE & 36 & PV & $Y$ & PNV & PNV & CURE \\
\hline 12 & CURE & $\mathrm{N}$ & PNV & PNV & CURE & 37 & PV & $Y$ & PNV & CURE & CURE \\
\hline 13 & PV & $Y$ & PNV & PNV & CURE & 38 & PV & $Y$ & PNV & CURE & CURE \\
\hline 18 & CURE & $\mathrm{N}$ & PNV & PNV & PNV & 43 & CURE & $\mathrm{N}$ & CURE & CURE & CURE \\
\hline
\end{tabular}


Table 1. Evolution of cysts at 24 weeks.

\begin{tabular}{|c|c|c|c|c|c|c|c|c|c|c|c|}
\hline Order & $4 w$ & New procedure & $8 w$ & $12 w$ & $24 w$ & Order & $4 w$ & New procedure & $8 w$ & $12 w$ & $24 w w$ \\
\hline 19 & CURE & $\mathrm{N}$ & CURE & CURE & CURE & 44 & PV & $Y$ & PV & PV & PV \\
\hline 20 & PV & $Y$ & PV & PNV & CURE & 45 & CURE & $\mathrm{N}$ & PNV & CURE & CURE \\
\hline 21 & PV & $Y$ & PV & PV & PV & 46 & PV & $Y$ & PV & CURE & CURE \\
\hline 22 & PV & $Y$ & PV & PNV & CURE & 47 & CURE & $\mathrm{N}$ & CURE & CURE & CURE \\
\hline 23 & LOST FOLLOW-UP & & & & & 48 & PNV & $\mathrm{N}$ & CURE & CURE & CURE \\
\hline 24 & LOST FOLLOW-UP & & & & & 49 & PV & $Y$ & PV & PV & PV \\
\hline
\end{tabular}

After 24 weeks of the first procedure, 27 (57.4\%) cysts evolved for healing and 20 (42.6\%) cysts showed persistence. Among those who persisted, six (12.8\%) cysts were palpable and non-visible and 14 (29.8\%) cysts were palpable and visible (Figure 1).

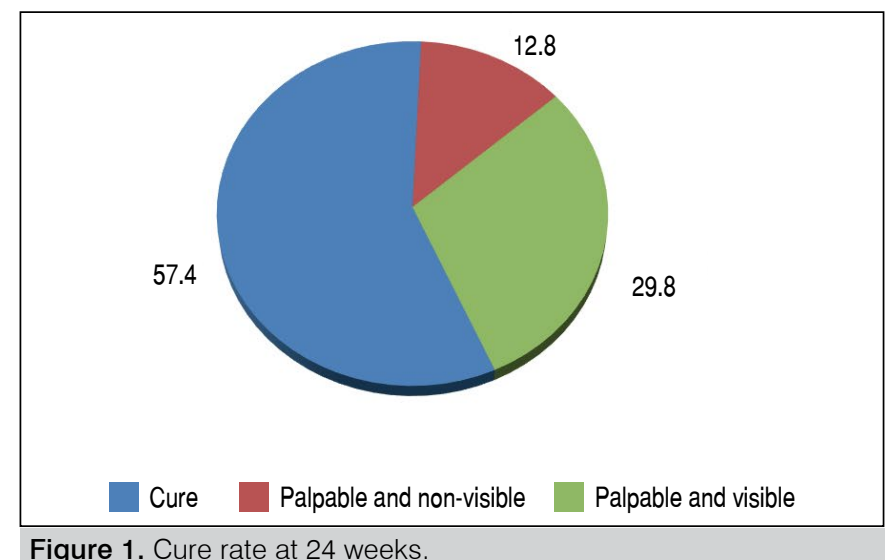

When we evaluated the evolution of pain caused by the cyst at different times, there was a significant decrease in the healing group, and in the palpable and non-visible group. There was no difference in the palpable and visible group (Figure 2). Only $10 \%$ of patients used analgesics.

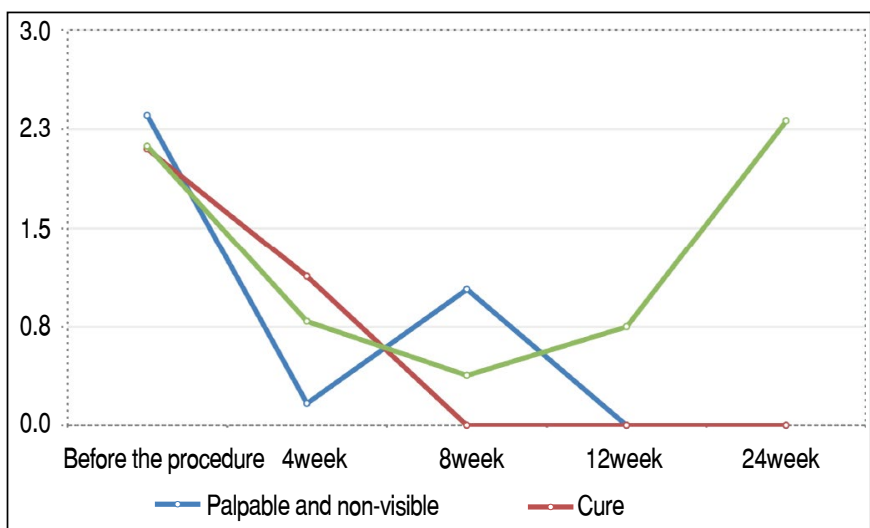

Figure 2. Evolution of the pain symptom caused by the cyst at different evaluation times.

There were no differences in grip strength and cuff range of motion when compared the pre-procedure and 24 weeks after procedure moments.

Regarding complications of the procedure, nine (19\%) patients reported pain, 46 (97\%) patients reported edema and 45 (95\%) reported hyperemia and one (2\%) patient presented superficial skin ulceration. No patient required a procedure to treat complications (Figure 3).

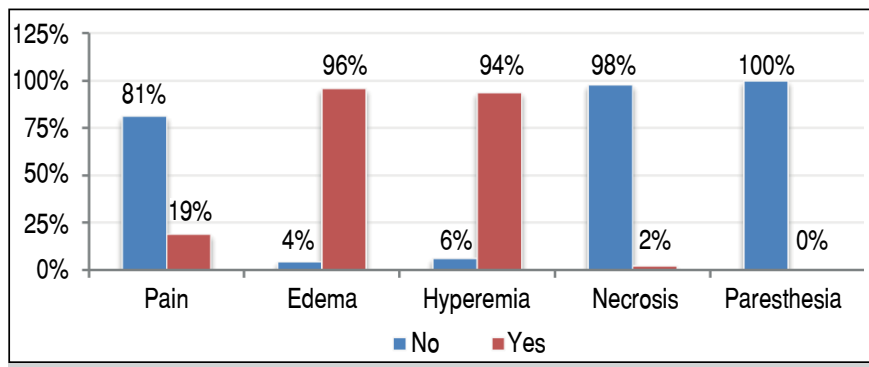

Figure 3. Distribution of complications.

In the evaluation of the Quick DASH questionnaire, when we stratified by groups, for the cured there was a significant decrease in the scores, but it was not significant in the palpable and non-visible groups and in the palpable and visible group (Table 2).

In the evaluation of the Brief Michigan Hand Questionnaire, when we stratified by groups, there was a significant increase in the scores for the healing group and for the the palpable and non-visible group, and not significant increase for the palpable and visible group (Table 2).

Table 2. Comparison of moments for Quick DASH and Brief Michigan Hand Questionnaire by group.

\begin{tabular}{|c|c|c|c|c|c|c|}
\hline \multirow{2}{*}{\multicolumn{2}{|c|}{ Week }} & \multicolumn{2}{|c|}{ Quick DASH. } & \multirow{2}{*}{\multicolumn{2}{|c|}{$\begin{array}{c}\text { Brief Michigan } \\
\text { Mean Week }\end{array}$}} & \multirow[b]{2}{*}{ P-value } \\
\hline & & \multirow{2}{*}{$\begin{array}{c}\text { Mean } \\
7.12\end{array}$} & \multirow{3}{*}{\begin{tabular}{|c|} 
P-value \\
0.010
\end{tabular}} & & & \\
\hline \multirow{2}{*}{ Cure } & 0 & & & 0 & 85.2 & \multirow{2}{*}{$<0.001$} \\
\hline & 24 & 0.35 & & 24 & 99.5 & \\
\hline \multirow{2}{*}{ Palpable and non-visible } & 0 & 6.04 & \multirow{2}{*}{0.136} & 0 & 85.0 & \multirow{2}{*}{0.035} \\
\hline & 24 & 1.50 & & 24 & 95.1 & \\
\hline \multirow{2}{*}{ Palpable and visible } & 0 & 8.34 & \multirow{2}{*}{0.733} & 0 & 84.2 & \multirow{2}{*}{0.072} \\
\hline & 24 & 9.56 & & 24 & 88.8 & \\
\hline
\end{tabular}

\section{DISCUSSION}

We had three follow-up losses, an acceptable number in the literature. ${ }^{15}$ We followed 45 patients, a number comparable to other studies related to the theme such as those by Suen et al. ${ }^{6}$ and G. Mackie et al. ${ }^{16}$

Diabetic patients were excluded due to the risk of hyperglycemia by hypertonic glucose use, although it is a concern only when larger volumes are used. ${ }^{11,12}$

Paramhans et al., ${ }^{1}$ Kuliński et al. ${ }^{2}$ and Dogo et al. ${ }^{9}$ also found a higher incidence of cysts in women.

Paramhans et al. ${ }^{1}$ and Hernández Espinosa et al. ${ }^{10}$ also presented prevalence of wrist dorsal cysts in young adults.

Kuliński et al., ${ }^{2}$ in 2017, also reported no predilection on the affected side of the sore cysts of the wrist.

Chatterje et al. $^{8}$ and Berghoff and Amadio ${ }^{17}$ also used the same method for the diagnosis of dorsal cyst of the wrist, with clinical examination and ultrasound examination. 
The conducted procedure method, called single dart, was chosen because it was described in the literature as causing fewer complications. ${ }^{8,13}$

Otu et al. ${ }^{18}$ and Chatterje et al., ${ }^{8}$ in their research on synovial cyst of the wrist, also followed-up for 24 weeks.

Regarding the treatment options described in the literature, simple aspiration presents great variation in the recurrence rate, from 15 to $69 \%$. $^{19,20}$

Aspiration and infiltration with corticosteroids present recurrence rates of 33 to $58 \%$, which may lead to skin hypopigmentation. ${ }^{21}$ The mechanism of action of sclerosing substances occurs by the cell lesion, altering the water balance by means of the cell gradient, dehydrating and denaturizing the cell membrane. ${ }^{22}$

Hyperosmotic sclerosing agents, such as hypertonic glucose and sclerosing detergents such as polydocanol and tetradecyl sulfate, are the safest and most effective used for medical procedures. ${ }^{16}$ For a sclerosing agent to be considered ideal, it must be able to produce tissue obliteration and not cause complications. ${ }^{16}$

Using hypertonic serum, in aspiration and sclerotherapy of the cyst, Dogo et al. ${ }^{9}$ reported no recurrence of the synovial cyst. Mackie et al. ${ }^{16}$ used sodium tetradel disulfate with a recurrence rate of $94 \%$. Hernández Espinosa et al., ${ }^{10}$ using polydocanol, presented a recurrence rate of only $3.6 \%$.

Chatterje et al. ${ }^{8}$ in 2014, published recurrence rates of $20 \%, 31 \%$ and $35 \%$, respectively, using triamcinolol, hyaluronidase and sodium tetradecyl sulfate.

In our study, we had $57.4 \%$ cure in 24 weeks. Of the six patients after 6 months that were in the group palpable and non-visible cysts, five (84\%) refused surgical treatment because they did not report pain and there was no aesthetic complaint. These results were not part of the healing group, if added, they would increase the cure rate to $68 \%$.

After 4 weeks, we found a cure rate of $23.4 \%$. With the second procedure, we increased the cure rate to more than $50 \%$. Chatterje et al., in his randomized study, reported to have conducted up to three procedures, but not informing the number of procedures in each cyst. In our study, complications using hypertonic glucose $75 \%$ were frequent, but with low morbidity. No complications required a specific treatment and influenced the pain intensity assessed by VAS. The ulceration found in one patient in our study may have been caused by a procedure error with infusion of the sclerosing agent into the subcutaneous tissue or by extravasation of the sclerosing agent out of the cyst. We found reports of skin ulceration in $1 \%$ of patients treated with hyaluronidase and in $5 \%$ of patients treated with sodium tetradecyl sulfate. ${ }^{8}$

Chatterjee et al. ${ }^{8}$ reported wrist stiffness with the use of triamcinolol, hyaluronity and sodium tetradecyl sulfate. We had no wrist stiffness when comparing the cuff range of motion after 24 weeks.

Dogo et al., ${ }^{9}$ using hypertonic serum, reported that $20 \%$ of their patients needed analgesics for severe pain. In our study, only $10 \%$ of the patients used the prescribed analgesic, showing an advantage over other sclerosing agents, since pain is a factor of discomfort and treatment interruption. Regarding wrist pain, as assessed by VAS, we noticed that in the healing groups and in the palpable and non-visible group, there was a significant improvement in pain, evolving to absence of pain at 8 and 12 weeks, respectively. However, in the palpable and visible group, pain remained present even after 24 weeks, showing that pain is directly related to the presence of the cyst.

In the healing group, there was a significant improvement in the Quick Dash and Brief Michigan functional questionnaires. This improvement was mainly due to pain, which was the main complaint of patients.

In the palpable and non-visible group there was significant improvement only in the Brief Michigan functional questionnaire, which was also due to the appearance of the hand, not addressed in the Quick Dash questionnaire.

As limitations of our study, we cite the short follow-up period, since recurrences can be observed for up to 2 years after aspiration.

\section{CONCLUSION}

The treatment of dorsal synovial cyst of the wrist with aspiration and sclerotherapy with hypertonic glucose $75 \%$ is a new tool for conservative treatment of the cyst, with a cure rate of $57.4 \%$ at 24 weeks after the procedure.

AUTHORS' CONTRIBUTIONS: Each author contributed individually and significantly to the development of this article. FAP: writing, data analysis and procedures; JBGS: writing, data analysis and procedures; CHF: article conceptualization and review; LRN: writing, data analysis and procedures; FF: article conceptualization and review.

\section{REFERENCES}

1. Paramhans D, Nayak D, Mathur RK, Kushwah K. Double dart technique of instillation of triamcinolone in ganglion over the wrist. $\mathrm{J}$ Cutan Aesthet Surg. 2010;3(1):29-31.

2. Kuliński S, Gutkowska O, Mizia S, Gosk J. Ganglions of the hand and wrist: retrospective statistical analysis of 520 cases. Adv Clin Exp Med. 2017;26(1):95-100

3. Gumuş N. A new sclerotherapy technique for the wrist ganglion: transcutaneous electrocauterization. Ann Plast Surg. 2009;63(1):42-4

4. Ho PC, Griffiths J, Lo WN, Yen CH, Hung LK. Current treatment of ganglion of the wrist. Hand Surg. 2001;6(1):49-58.

5. Barnes WE, Larsen RD, Posch JL. Review of ganglia of the hand and wrist with analysis of surgical treatment. Plast Reconstr Surg. 1964;34:570-8.

6. Suen M, Fung B, Lung CP. Treatment of ganglion cysts. ISRN Orthop. 2013;2013:940615

7. Athanasian EA. Bone and soft tissue tumors. In: Wolfe SW, Hotchkiss RN, Pederson WC, Kozin SH, Cohen MS, editors. Green's operative hand surgery. 7th ed. Amsterdam: Elsevier; 2016. p. 2001.

8. Chatterjee S, Basu A, Gupta S, Biswas S. Comparative study of recurrence and complications using various sclerosants by single dart technique in treatment of ganglion cysts. Indian J Surg. 2014;76(5): 350-3.

9. Dogo D, Hassan AW, Babayo U. Treatment of ganglion using hypertonic saline as sclerosant. West Afr J Med. 2003;22(1):13-4.

10. Hernández Espinosa OA, Sasturain Miranda ME, Labrada Blanco PO. Uso de polidocanol en el tratamiento conservador del ganglión del carpo. Rev Cubana Ortop Traumatol. 1997;11(1-2):37-40.

11. Glicose 75\%. Medication package insert. Goiânia: Halex Istar; 2009.
12. Belczak CEQ, Godoy JMP, Belczak J Neto, Cunha AGP, Belczak SQ. Variation in level of glycemia after sclerotherapy performed with $10 \mathrm{ml}$ of $75 \%$ hypertonic glucose. J Vasc Bras. 2004:3(2):127-30.

13. Orfale AG, Araújo PMP, Ferraz MB, Natour J. Translation into Brazilian Portuguese, cultural adaptation and evaluation of the reliability of the disabilities of the arm, shoulder and hand questionnaire. Braz J Med Biol Res. 2005;38(2):293-302.

14. Fernandes CH, Raduan J Neto, Meirelles LM, Pereira CNM, Santos JBG, Faloppa F. Translation and cultural adaptation of the Brief Michigan Hand Questionnaire to Brazilian Portuguese language. Hand (NY). 2014;9(3):370-4.

15. Dumville JC, Torgerson DJ, Hewitt CE. Reporting attrition in randomised controlled trials. BMJ. 2006;332(7547):969-71.

16. Mackie IG, Howard CB, Wilkins $P$. The dangers of sclerotherapy in the treatment of ganglia. J Hand Surg Br. 1984;9(2):181-4.

17. Berghoff RA Jr, Amadio PC. Dorsal wrist ganglion: cause of dorsal wrist pain Orthopade. 1993;22(1):30-5.

18. Otu AA. Wrist and hand ganglion treatment with hyaluronidase injection and fine needle aspiration: a tropical African perspective. J R Coll Surg Edinb. 1992;37(6):405-7.

19. Zubowicz VN, Ishii $\mathrm{CH}$. Management of ganglion cysts of the hand by simple aspiration. J Hand Surg Am. 1987;12(4):618-20.

20. Stephen AB, Lyons AR, Davis TR. A prospective study of two conservative treatments for ganglia of the wrist. J Hand Surg Br. 1999;24(1):104-5.

21. Varley GW, Needoff M, Davis TR, Clay NR. Conservative management of wrist ganglia: aspiration versus steroid infiltration. J Hand Surg Br. 1997;22(5):636-7.

22. Yiannakopoulou E. Safety concerns for sclerotherapy of telangiectases, reticular and varicose veins. Pharmacology. 2016;98(1-2):62-9. 